\title{
Hospitalization of children for asthma in the Brazilian Amazon: trend and spatial distribution
}

\author{
Pâmela R. S. Silva, ${ }^{1}$ Antonia M. Rosa, ${ }^{2}$ Sandra S. Hacon, ${ }^{3}$ Eliane Ignotti $^{4}$
}

\begin{abstract}
Objective: To analyze the distribution of hospitalizations of children for asthma in the states comprising the Brazilian Amazon, as well as the variations of hospitalization according to climatic seasonality.

Methods: A descriptive study of the distribution of hospitalizations for asthma of individuals aged 0 to 14 years living in the Brazilian Amazon, according to trend, spatial distribution, and climatic seasonality over the period from 2001 to 2007. We used the database of authorizations for hospitalizations (AIH) of the Hospital Information System (SIH/SUS) of the Brazilian Ministry of Health.

Results: The spatial distribution of hospitalizations for asthma resembles the configuration of the "arc of deforestation," mainly in the states of Rondônia and Maranhão. The distribution of annual hospitalizations for asthma decreased from 8.1 to 2.6 hospitalizations/1,000 inhabitants during the period. There was a peak of hospitalizations in March and May in all states. The seasonal differences were on average $10 \%$, with the highest rates during the rainy season.

Conclusion: We concluded that hospitalizations for asthma are more frequent in the months of more intense rainfall, with greater magnitude in the states comprising the "arc of deforestation" in the Brazilian Amazon, especially Rondônia and Maranhão.
\end{abstract}

J Pediatr (Rio J). 2009;85(6):541-546: Asthma, Amazon, hospitalization, children, spatial distribution.

\section{Introduction}

Asthma is a persistent chronic inflammatory lung disease that can be totally or partially reversed, being characterized by airway obstruction. In addition to airway inflammation, it also includes different severity levels of bronchial hyperresponsiveness triggered by several stimuli. ${ }^{1}$

Personal and family history of atopy, presence of bronchial hyperresponsiveness, and increased frequency of wheezing episodes are predisposing factors for asthma. ${ }^{2}$ Low socioeconomic conditions may also increase the chance of asthma in children. ${ }^{3}$ Environmental or occupational pollutants, climate changes, contact with dust, mold, pollen, strong smells, animal fur, smoke, consumption of certain foods and drugs, such as aspirin and beta-blockers, as well as flu and colds, are strong determinants of asthma or exacerbation of asthma. 4

With regard to hospitalizations for asthma related to the higher severity of the disease, the following are considered to be risk factors: deficient primary health care services, home smoking, ${ }^{3,5}$ and low birth weight. ${ }^{6}$ Three hundred million people suffer from asthma in the world. ${ }^{7}$

1. Acadêmica de Enfermagem, Universidade do Estado de Mato Grosso (UNEMAT), Cáceres, MT, Brazil.

2. Orientadora, Docente, Bacharelado em Enfermagem, UNEMAT, Cáceres, MT, Brazil.

3. Docente, Programa de Mestrado e Doutorado em Saúde Pública e Meio Ambiente, Escola Nacional de Saúde Pública (ENSP), Fundação Instituto Oswaldo Cruz (FIOCRUZ), Rio de Janeiro, RJ, Brazil.

4. Coorientadora, Docente, Bacharelado em Enfermagem, UNEMAT, Cáceres, MT, Brazil.

This study was conducted at Universidade do Estado do Mato Grosso (UNEMAT), Cáceres, MT, Brazil.

Financial support: FAPEMAT PPSUS/2006 and CNPq/Proc 420199/2005-5

No conflicts of interest declared concerning the publication of this article.

Suggested citation: Silva PR, Rosa AM, Hacon SS, Ignotti E. Hospitalization of children for asthma in the Brazilian Amazon: trend and spatial distribution. J Pediatr (Rio J). 2009;85(6):541-546.

Manuscript submitted Aug 11 2009, accepted for publication Sep 302009.

doi:10.2223/JPED.1952 
In 2002, the Brazilian Unified Health System (Sistema Único de Saúde, SUS) recorded approximately 370,000 hospitalizations for asthma, being the fourth most frequent cause of hospitalization in all age groups according to data calculated based on the records of the IT Department of SUS (DATASUS). ${ }^{8}$

In Brazil, the mean prevalence of active asthma in 2003 among children from 6 to 7 years old and among adolescents from 13 to 14 years old was 24.3 and $19 \%$, respectively. This prevalence rate seems to increase in regions closer to the Equator line. ${ }^{9}$

According to Lasmar et al., ${ }^{10}$ most asthmatic children are hospitalized during their first year of life. Children with more severe asthma are prone to have repeated crises and, as a consequence, they may be hospitalized for several times. ${ }^{11}$ For these children, hospitalizations are related to school absence and important family suffering. Furthermore, for the health system, it is a costly procedure in spite of the fact that it is a preventable outcome when there is adequate outpatient care. ${ }^{12}$

Some studies have demonstrated a seasonal relation in terms of hospitalizations and outpatient medical visits for asthma in several regions of Brazil.13,14 With regard to the Brazilian Amazon, several studies have highlighted the importance of the association between climatic seasonality and occurrence of respiratory diseases, mainly in the drought season. ${ }^{15,16}$ This region is characterized by well-established drought and rainy seasons. Over the years, there has been intense anthropogenic activity, including unrestricted field burning and deforestation of large areas for farming and cattle breeding purposes and illegal wood extraction. Deforested areas are located mainly along an arc that includes the border of the Amazon region, concentrating more than $85 \%$ of the field burnings in Brazil during the drought season in this region. ${ }^{17}$

Because of the possible relation between hospitalizations for asthma and the seasonal variation, as well as due to the shortage of studies on this topic in the region, the objective of the present study is to analyze the distribution of hospitalizations of children for asthma in the states comprising the Brazilian Amazon and the variations of hospitalization rates according to climatic seasonality.

\section{Material and method \\ Study design}

Descriptive study of hospitalizations for asthma of individuals aged between 0 and 14 years living in the Brazilian Amazon from 2001 to 2007.

\section{Study population and area}

The Brazilian Amazon is a geopolitical region established in 1966 for regional planning purposes. In Brazil, the
Amazon includes the states of Acre, Amapá, Amazonas, Pará, Rondônia, Roraima, Tocantins, Mato Grosso, and part of Maranhão. According to the demographic census of 2007, approximately 24 million people lived in this region, which accounts for $12.8 \%$ of the national population. ${ }^{18}$ Even though not all its territory is part of the Brazilian Amazon, the state of Maranhão was included in the present study to simplify the analysis conducted according to microregions and states.

Most deforestation activities are carried out in the region called "arc of deforestation," which starts in the south region of Maranhão, including the north of Tocantins, the east and south of Pará, the south of Amazonas, the east of Acre, Mato Grosso, and Rondônia. It encompasses around 520 municipalities that together have a population of more than 10 million inhabitants. 19

\section{Variables and sources of data}

We searched the databases of authorizations for hospitalizations (autorizações de internações hospitalares, $\mathrm{AIH}$ ) of the Hospital Information System (sistema de informações hospitalares, SIH/SUS) of the Brazilian Ministry of Health. ${ }^{8}$ Population data according to age group and digital maps were provided by the Brazilian Institute of Geography and Statistics (Instituto Brasileiro de Geografia e Estatística, IBGE). ${ }^{20}$ We used the chapter $X$ of the International Classification of Diseases - 10th Revision (ICD-10), ${ }^{21}$ codes J45.0, J45.1, J45.8, J45.9, and 346 of people living in the Brazilian Amazon from 2001 to 2007. We selected the authorizations for hospitalizations with the following characteristics: paid, non-selective, short hospital stay (type 1) according to the years of hospitalization and place of residence of the children who were 14 years 11 months and 29 days old up to the date of hospitalization.

\section{Data analysis}

We calculated the rates of hospitalization of children younger than 15 years old for asthma according to the microregions of the states comprising the Brazilian Amazon for the period between 2001 and 2007. With the purpose of illustrating the distribution of rates, we designed maps including the identification of the areas with the highest concentration of events or hot spots according to the microregion of residence. In the descriptive spatial analysis performed using the computer program TerraView 3.2.0, the indicator of rate of hospitalization of children for asthma was presented based on kernel estimate, using a chart containing 200 columns over the region as a parameter, with quadratic equation algorithm, adaptive radius, and density calculation with 10 slices and accuracy 12 . In the matrix calculation, we considered the centroids of microregions; however, for better viewing, the vectorial map was designed according to the states. Based on the 
analysis of the spatial distribution of hospitalization rates for asthma, we selected the states with areas of higher rates regarding this indicator. Hospitalization rates were presented as annual and monthly series. With the purpose of analyzing climatic seasonality, we used the proportion of hospitalizations for asthma, combining data related to the period from April to October, which is defined as the drought season, and data related to the period from November to March, defined as the rainy season. Comparisons of the hospitalizations according to seasonality were carried out using the ratio of the absolute number of hospitalizations and the chi-square test for comparison of proportions at $5 \%$ significance level.

\section{Ethical considerations}

The research project was approved by the Research Ethics Committee of Hospital Universitário Júlio Müller (HUJM), Cuiabá, Brazil, register no. 387/CEP/HUJM/07, on Jun 18, 2007.

\section{Results}

Figure 1 shows that the spatial distribution of hospitalizations for asthma of children younger than 15 years old is resembles the configuration of the "arc of deforestation." In the states of Maranhão and Rondônia some microregions have the main hot spots with rates of up to 3.2 hospitalizations/1,000 children in Rondônia in 2001 and 3.8 in Maranhão in 2002 without any apparent changes throughout the series being studied in this distribution.

Figure 2 shows that there was an increase in the number of hospitalizations of children for asthma between 2001 and 2007. The state of Rondônia had the highest rates of hospitalization for asthma over the period, with a decrease from 8.2 to 5.8 hospitalizations/1,000 children between 2002 and 2003, followed by the state of Mato Grosso, which had lower rates than Pará only in 2007, the last year of the series.

In the monthly distribution of rates of hospitalization of children for asthma according to the states (Figure 3), we found that hospitalizations occurred mainly from the end of the rainy season up to the beginning of the drought season. The highest rates of hospitalizations for asthma were identified in the months of May and June in the state of Rondônia, with rates of 4.3 and 4.9 hospitalizations $/ 1,000$ children, respectively. In the other states, we found a peak of hospitalizations in the months of March and May. In the state of Mato Grosso, we found rates of 2.9 and 3.0 hospitalizations $/ 1,000$ children in the months of March and May, respectively.

We found an average of $10 \%$ of higher proportion of hospitalizations in the rainy season in the states included in the present study, with a significant statistical difference

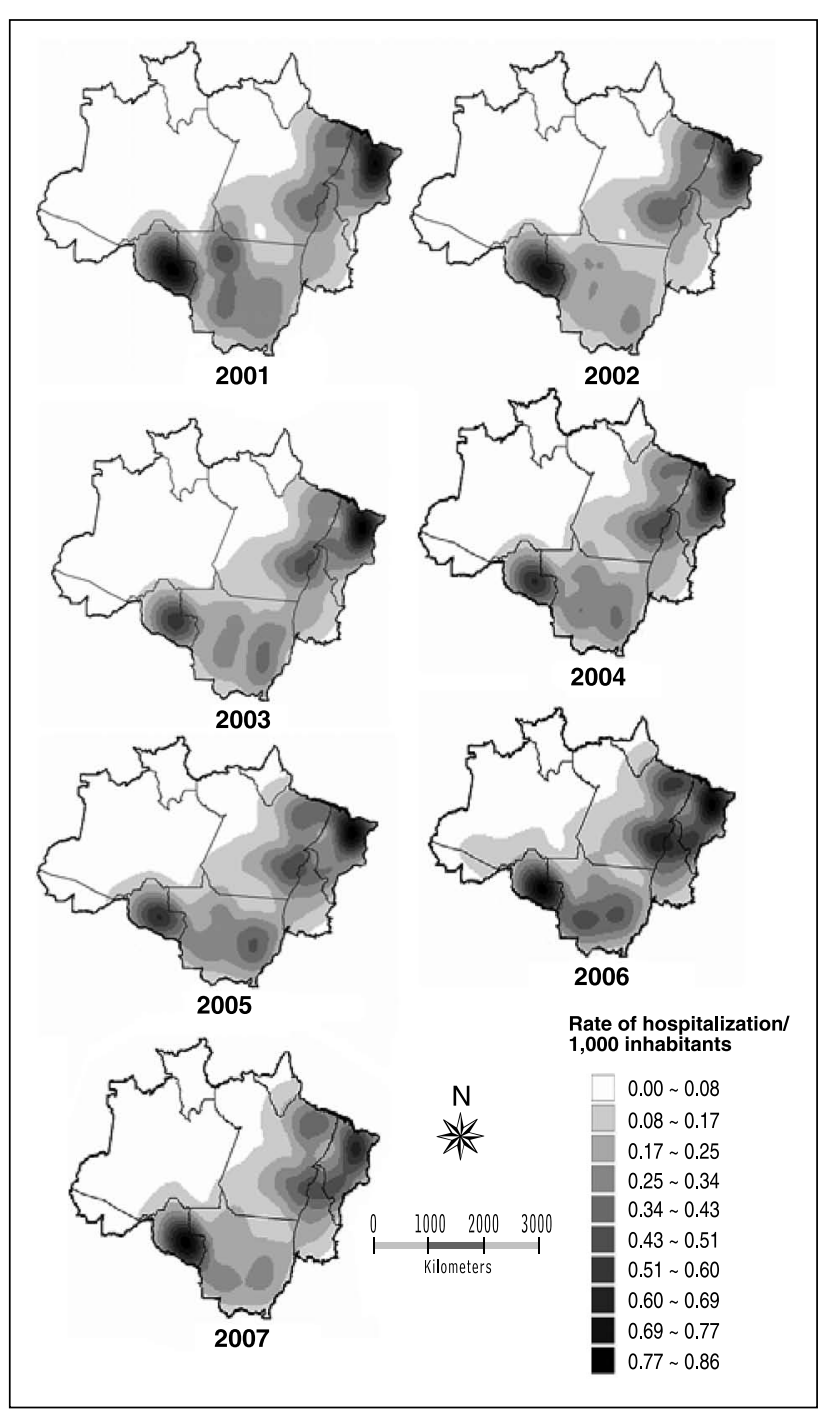

Figure 1 - Kernel distribution according to the annual rate of hospitalizations (\%o children) for asthma of children younger than 15 years old in the microregions of the Brazilian Amazon from 2001 to 2007

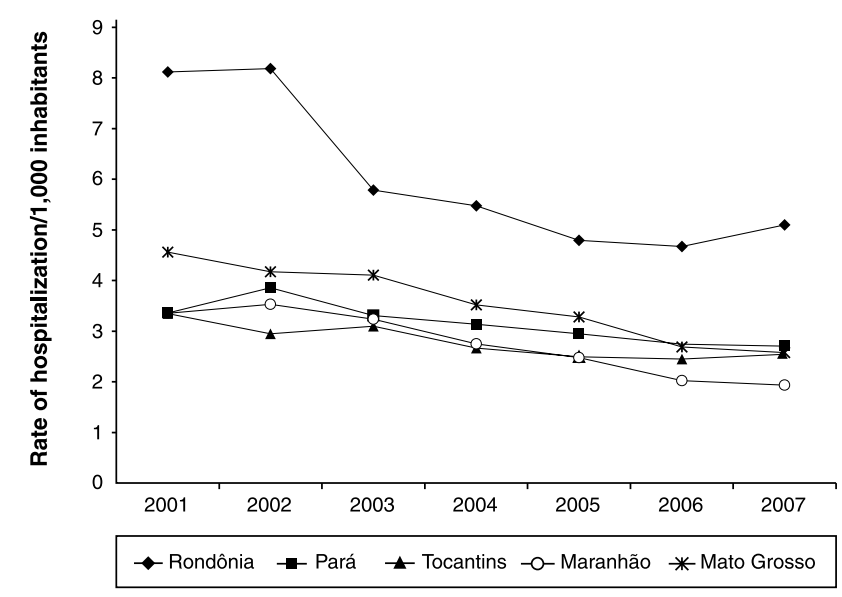

Figure 2 - Distribution of the annual rate of hospitalization (\%o children) for asthma of children younger than 15 years old according to states (Rondônia, Pará, Tocantins, Maranhão, and Mato Grosso; 2001 to 2007 - Brazil) 


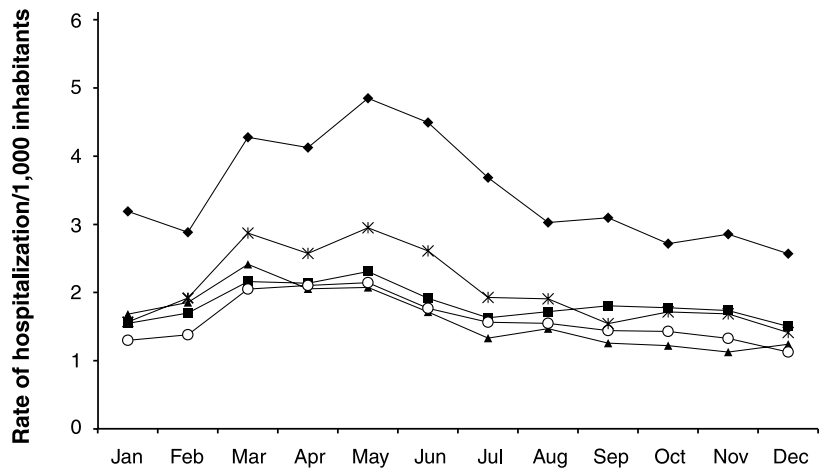

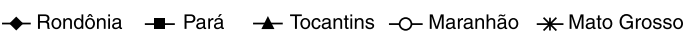

Figure 3 - Distribution of the monthly rate of hospitalization (\%o children) for asthma of children younger than 15 years old according to states (Rondônia, Pará, Tocantins, Maranhão, and Mato Grosso - Brazil) from 2001 to 2007

ranging from $6 \%$ in Pará to $36 \%$ in Tocantins. In the state of Mato Grosso, the number of hospitalizations of children was $17 \%$ higher in the rainy season when compared with the drought season (Table 1 ).

\section{Discussion}

The spatial distribution of hospitalizations for asthma makes it easier to determine the magnitude of the problem affecting the children who live in the Brazilian Amazon. According to Barcellos \& Bastos, ${ }^{22}$ the use of geoprocessing enables researchers to have an overview of the social, economic and environmental context where the disease develops. The geographical distribution of hospitalizations of children for asthma was demonstrated in the present study by means of the environmental characteristics of the region affected by the anthropogenic activity in terms of land use with forest destruction due to deforestation and field burning.

The highest rates of hospitalizations of children for asthma found in the east and south borders of the Brazilian Amazon were found in the areas of recent settlements. In these areas, most municipalities were created as a result of settlement projects supported by the Brazilian government. 23

With regard to the distribution of hospitalizations, the states of Rondônia and Maranhão stood out in comparison to the other states. However, when we analyzed the rates per state, Maranhão did not show the highest hospitalization rates, with Rondônia and Mato Grosso showing the areas having the highest occurrence of hospitalizations of children younger than 15 years old.

The variation in the rates of hospitalization for asthma in Maranhão is in disagreement with that of other states. In Maranhão, two microregions had high rates (Itapecuri Mirim and Gurupi). The microregions with the highest rates of hospitalization for asthma are located in the areas surrounding the state capital, São Luís, in the North mesoregion, while those areas with the lowest rates were closer to the state of Piauí and the Northeast region of Tocantins, in the South mesoregion, an area characterized by cerrado and which is drier than the other regions. ${ }^{18}$ On the other hand, in Mato Grosso and Rondônia the variations in the rates between the microregions are less significant, even though these states had the highest aggregate rates.

According to the United Nations Development Program, ${ }^{24}$ Maranhão has the lowest human development index (HDI) in the country. It is probable that the socioeconomic conditions of the families living in Maranhão might have an influence on the rates of hospitalizations for asthma found in that state. In a study conducted in Maranhão, the authors found that those children who were more often hospitalized for any reasons were the children belonging to families with family income up to one minimum salary. ${ }^{25}$

Table 1 - Proportion and ratio of hospitalizations for asthma between the drought and rainy seasons of children younger than 15 years old (Rondônia, Pará, Tocantins, Maranhão, and Mato Grosso - Brazil) from 2001 to 2007

\begin{tabular}{|c|c|c|c|c|c|}
\hline \multirow[b]{2}{*}{ States } & \multirow[b]{2}{*}{ Rain, n (\%) } & \multirow[b]{2}{*}{ Drought, n (\%) } & \multicolumn{3}{|c|}{ Drought/rain } \\
\hline & & & Ratio & Chi-square & $\mathbf{p}$ \\
\hline Rondônia & $9,721(51.79)$ & $9,050(48.21)$ & 1.07 & 24.10 & 0.000 \\
\hline Pará & $24,660(51.56)$ & $23,171(48.44)$ & 1.06 & 46.56 & 0.000 \\
\hline Tocantins & $4,298(57.67)$ & $3,155(42.33)$ & 1.36 & 171.19 & 0.000 \\
\hline Maranhão & $19,976(52.21)$ & $18,286(47.79)$ & 1.09 & 74.50 & 0.000 \\
\hline Mato Grosso & $10,244(53.83)$ & $8,788(46.17)$ & 1.17 & 111.06 & 0.000 \\
\hline Total & $68,899(52.45)$ & $62,450(47.55)$ & 1.10 & 314.69 & 0.000 \\
\hline
\end{tabular}

Calculated based on data of Datasus/SIH, $2008 .^{8}$ 
In addition to the environmental determinants, the quality and the coverage of primary health care services can be related to the rates of hospitalization of children for asthma both in Rondônia and Maranhão. Due to the lack of monitoring and control of the primary health care service provided, this health sector can have some flaws. ${ }^{26}$

The decreasing trend of hospitalizations of children for asthma in the Brazilian Amazon seems to be similar to the hospitalization rates in Brazil. According to the data of DATASUS, 8 hospitalizations for any reasons of children younger than 15 years old in the whole country decreased from 2,532,577 in 2001 to $1,819,511$ hospitalizations in 2007. Hospitalizations for asthma also had a decrease from 210,743 hospitalizations in 2001 to 167,104 hospitalizations in 2007.

In spite of being relevant, the objective of the present study was not to investigate the determinant factors of the decreasing trend of hospitalizations of children for asthma in the Brazilian Amazon. However, asthma is difficult to diagnose, and most of the cases are identified only when there is relapse of the first hospitalization. According to the Brazilian Association of Asthmatics (Associação Brasileira de Asmáticos, ABRA), ${ }^{27}$ asthma is often diagnosed as pneumonia, bronchitis, or lower airway infection. In addition, there is low reliability in terms of the record of the main diagnosis of the hospitalizations occurred in Brazil. 28 The decision of hospitalizing a patient is influenced by the financial aspects, as well as by the availability of hospital beds and by professional practices and, therefore, it not strictly related to the need of health care. ${ }^{29}$

The decrease in the number of hospitalizations between the months of December and February may be explained by the operational seasonality, consisting in the period during which most health professionals go on vacation. ${ }^{16}$ Nevertheless, several studies conducted in Brazil have shown an association between air pollution and increase in the number of hospitalizations for asthma. ${ }^{30,31}$ However, it is expected that the drought months, during which there are high levels of air pollution due to the field burning activity in the region, are related to the higher rates of hospitalizations for asthma. Nevertheless, this association was not found in the present study, since most asthmatic children were hospitalized during the months of the rainy season in the region. Such seasonal behavior, which is different from what was expected, may be caused by several factors. Croce et al. ${ }^{32}$ reported that the increase in the humidity during the rainy season leads to an increase in the prevalence of funguses and mites that are important allergens for the occurrence of asthmatic crises. Pauliquevis et al. ${ }^{33}$ showed that the concentration of biogenic material made up of the release of fragments of leaves, pollen grains, bacteria and funguses in the rainy season is higher than in the drought season. In addition, in some areas of the Amazon region, which suffer the effects of field burnings, the release of this material increases 10 times.

Valença et al., ${ }^{14}$ in a study conducted in Gama, in the Federal District, found an increase in the number of asthmatic crises 2 months after the increase in the rainfall also related to the time funguses and mites take to increase their concentration.

Rodrigues et al. ${ }^{34}$ found that the highest rates of hospitalization for asthma among elderly people in the Brazilian Amazon has occurred in the drought season, which is in disagreement with the Valença et al. ${ }^{14}$ Some factors that are inherent to the elderly population may explain this finding.

The limitations of the present study are related to aspects that are typical of descriptive studies conducted using secondary databases. However, our study provides an overview of the areas with higher rates of hospitalizations for asthma, at the same time that it identifies the microregions that are the most relevant for the development of measures focused on the monitoring and control of the disease. The predominance of hospitalizations at the end of the rainy period in areas where there is high exposure to air pollution during 3 to 4 months per year evidences the importance of investigating the risk factors for asthma related to the way of life and to changes in the Amazonian ecosystem.

We conclude that the hospitalizations of children for asthma are more frequent in the months of more intense rainfall, with greater magnitude in the states that comprise the "arc of deforestation" in the Brazilian Amazon, especially Rondônia and Maranhão.

\section{Acknowledgements}

The authors would like to thank Diego Ricardo Xavier da Silva for his help designing the figures.

\section{References}

1. Gama ME. Tratamento da asma na criança. PAHO. 2006. [website] http://www.paho.org/Portuguese/AD/DPC/CD/aiepi-1-14.pdf. Access: $31 / 10 / 2008$.

2. Wannmacher $L$. Tratamento medicamentoso da asma em crianças. OPAS. 2006;3:1-6. [website] http://portal.saude.gov.br/portal/ arquivos/pdf/v3n9_asma_crianca.pdf. Access: 31/10/2008.

3. Gonçalves-Silva RM, Valente JG, Lemos-Santos MG, Sichieri R. Tabagismo no domicílio e doença respiratória em crianças menores de cinco anos. Cad Saude Publica. 2006;22:579-86.

4. GINA - Global Initiative for Asthma [website]. Pocket Guide for Asthma Management and Prevention. MCR, Inc. http:// www.ginasthma.com/Resources.asp? $|1=4 \&| 2=0$. Access: 15/09/2008.

5. Pereira ED, Torres L, Macêdo J, Medeiros MM. Efeitos do fumo ambiental no trato respiratório inferior de crianças com até 5 anos de idade. Rev Saude Publica. 2000;34:39-43. 
6. Chatkin MN, Menezes AM. Associação entre baixo peso ao nascer e asma: uma revisão sistemática da literatura. Rev Panam Salud Publica. 2005; 17:102-9.

7. WHO - World Health Organization. [internet database].10 facts on asthma. http://www.who.int/features/factfiles/asthma/asthma_ facts/en/index.html. Access: 15/09/2008.

8. Departamento de Informática do SUS - DATASUS [website] Brasil: Ministério da Saúde. www.datasus.gov.br. Access: 07/05/2008.

9. Solé D, Wandalsen GF, Camelo-Nunes IC, Naspitz CK. Prevalence of symptoms of asthma, rhinitis, and atopic eczema among Brazilian children and adolescents identified by the International Study of Asthma and Allergies in Childhood (ISAAC). Phase 3. J Pediatr. 2006;82:341-6.

10. Lasmar L, Goulart E, Skurai E, Camargos P. Fatores de risco para hospitalização de crianças e adolescentes asmáticos. Rev Saude Publica. 2002;36:409-19.

11. Lasmar L, Camargos PA, Goulart EM, Sakurai E. Fatores de risco para readmissão hospitalar de crianças e adolescentes asmáticos. J Bras Pneumol. 2006;32:391-9.

12. Lenz ML, Pires NV, Stein AT, Flores R. Hospitalizações entre crianças e adolescentes no território de abrangência de um serviço de atenção primária. Rev Bras Saude Familia. 2008;18:9-14.

13. Godoy DV, Dal Zotto C, Bellicanta J, Weschenferder RF, Nacif SB. Doenças respiratórias como causa de internações hospitalares de pacientes do Sistema Único de Saúde num serviço terciário de clínica médica na região nordeste do Rio Grande do Sul. J Pneumol. 2001;27:193-8.

14. Valença LM, Restivo PC, Nunes MS. Variação Sazonal nos atendimentos de emergência por asma em Gama, Distrito Federal. J Bras Pneumol. 2006;32:284-9.

15. Saldanha CT, Silva AM, Botelho C. Variações climáticas e uso de serviços de saúde em crianças asmáticas menores de cinco anos de idade: um estudo ecológico. J Bras Pneumol. 2005;31:492-8.

16. Rosa AM, Ignotti E, Botelho C, Castro HA, Hacon SS. Doença respiratória e sazonalidade climática em menores de 15 anos em um município da Amazônia brasileira. J Pediatr. 2008;84:543-9.

17. INPE - Instituto Nacional De Pesquisas Espaciais [website]. Coordenação Geral de Observação da Terra. Relatório TécnicoCientífico. São José Dos Campos: Ministério Da Ciência E Tecnologia. http://urlib.net/sid.inpe.br/mtc-m18@80/2008/04.28.13.43. Access: $22 / 08 / 2008$.

18. IBGE - Instituto Brasileiro de Geografia e Estatística [website]. Brasília: Ministério do Planejamento, Orçamento e Gestão, 2004. Mapas de Bioma e Vegetação. http://www.ibge.gov.br/ home/presidencia/noticias/noticia_visualiza.php?id_noticia=169. Access: 29/06/2009.

19. Instituto Socioambiental [website]. Transformando o arco do desmatamento no arco do desenvolvimento sustentável: uma proposta de ações emergenciais. http://www.socioambiental. org/esp/novogov/proposta.htm. Access: 15/01/2009

20. IBGE - Instituto Brasileiro de Geografia e Estatística [website]. Brasília: Ministério do Planejamento, Orçamento e Gestão, 2007. www.ibge.gov.br. Access: 20/05/2008.
21. Centro Colaborador da OMS para a Classificação das Doenças em Português - CBCD. Tabelas da CID-10. Versão 2008. http://www. datasus.gov.br/cid10/v2008/cid10.htm. Access: 22/05/08

22. Barcellos C, Bastos FI. Geoprocessamento, ambiente e saúde: uma união possível? Cad Saude Publica. 1996;12:389-97.

23. Margulis S. Causas do Desmatamento da Amazônia Brasileira. $1^{a}$ ed. Brasília: Banco Mundial; 2002.

24. PNUD - Programa das Nações Unidas para o Desenvolvimento [website] Desenvolvimento Humano e ID. 2004. http://www. pnud.org.br/idh/. Access: 25/02/2009.

25. Silva AA, Gomes UA, Tonial SR, Silva RA. Fatores de risco para hospitalização de crianças de um a quatro anos em São Luís, Maranhão, Brasil. Cad Saude Publica. 1999;15:749-57.

26. Felisberto E. Monitoramento e avaliação na atenção básica: novos horizontes. Rev Bras Saude Mater Infant. 2004;4:317-21.

27. ABRA - Associação Brasileira de Asmáticos [site na internet]. Publicações. 2008. http://www.asmaticos.org.br/index.php?g_ edicao=artigos. Access: 15/12/2008.

28. Mendes AC, Silva Junior JB, Medeiros KR, Lyra TM, Melo Filho DA, Sá DA. Avaliação do Sistema de Informações Hospitalares - SIH/ SUS como Fonte Complementar na Vigilância e Monitoramento de Doenças de Notificação Compulsória. Informe Epidemiológico do SUS. 2000;9:67-86.

29. Merhy EE, Bueno WS. Organizações sociais: autonomia de quem e para que? Conferência Nacional de Saúde [website]. 1998. http://www.datasus.gov.br/cns/temas/OSreflex2.htm. Access: 21/03/2009.

30. Arbex MA, Cançado JE, Pereira LA, Braga AL, Saldiva $\mathrm{PH}$. Queima de biomassa e efeitos sobre a saúde. J Bras Pneumol. 2004;30:158-75.

31. Cançado JE, Braga A, Pereira LA, Arbex MA, Saldiva PH, Santos UP. Repercussões clínicas da exposição à poluição atmosférica. J Bras Pneumol. 2006;32:5-11.

32. Croce M, Vasconcelos DM, Manso ER, Duarte AJ. Poluição ambiental e alergia respiratória. Medicina, Ribeirão Preto. 1998;31:144-53.

33. Pauliquevis $\mathrm{T}$, Artaxo $\mathrm{P}$, Oliveira $\mathrm{PH}$, Paixão M. O papel das partículas de aerossol no funcionamento do ecossistema amazônico. Mudanças Climáticas. Cienc Cult .2007;59:48-50.

34. Rodrigues PC, Ignotti E, Rosa AM, Hacon S. Distribuição espacial da asma em idosos na Amazônia brasileira. J Bras Pneumol. 2009;supl 1R:R11.

\section{Correspondence:}

Eliane Ignotti

Av. República do Líbano, no 10, Bloco 10-61 - Senhor dos Passos CEP 78048-135 - Cuiabá, MT - Brazil

Tel/Fax: +55 (65) 3623.7044, +55 (65) 9947.4740

E-mail: eliane.ignotti@cnpq.br 